\title{
ІСТОРІЯ РОЗВИТКУ СОЦІАЛЬНИХ ІНСТИТУТІВ НА УКРАЇНСЬКИХ ЗЕМЛЯХ В ТВОРЧІЙ СПАДЩИНІ П. ЖИТЕЦЬКОГО
}

У нинішніх умовах зазіхань на українську територію, українську державність, спотворення підходів до розкриття історії нації, до здатності творити і розвивати власну державу як ніколи набуває актуальності звернення до поглядів та ідей педагогів-просвітників другої половини XIX початку XXст., які свою подвижницьку діяльність спрямовували на національну ідентифікацію українського народу, на розвиток унікальності та самобутності українців як нації, на доведення реального власного, повноцінного і самостійного історичного шляху розвитку та наявності значного потенціалу для формування українського суспільства.

Чільне місце в цьому контексті займає проблема розвитку та становлення соціальних інститутів на українських землях у різні часи. Адже зміна соціального, економічного та політичного устрою неможлива без інституційних трансформацій.

Вирішення цієї проблеми на підгрунті творчої спадщини вітчизняних педагогів, наукове вивчення їхніх ідей і поглядів сприятиме відродженню в Україні національної соціальнопедагогічної думки, забезпечить єдність і спадкоємність поколінь, стане рушійною силою процесу формування нової національно свідомої генерації.

Сьогодення вимагає ретельного вивчення, творчого осмислення та впровадження в практику кращих надбань української освіти та науки. Надзвичайно важливою постаттю в науковому житті української інтелігенщії кінця XIX - початку XX ст. став П. Житецький.

Звичайно, праці педагога вже в дечому застаріли, наприклад, деякі філологічні факти стали загальновідомими або були спростовані, а запропоновані ним навчально-методичні матеріали уже не відповідають сучасним вимогам освіти. Проте критичне використання його наукового надбання, зокрема етнографічних розвідок, реконструкції історичних подій, дає можливості для нового прочитання традиційної проблематики, об'єктивного, незаангажованого висвітлення подій і фактів.

Історичні аспекти розвитку та становлення соціальної педагогіки від первісного часу і до сьогодення висвітлено в праці Л. Бегас.

Стислий аналіз поглядів науковців періоду від давніх часів до середини XIX ст. щодо розвитку соціальної компетентності представлено в роботі О. Варецької.

Але жодної згадки про історію розвитку соціальних інститутів на українських землях в творчій спадщині П. Житецького ми не знаходимо, а отже погляди вченого ще не отримали повної об' єктивно-аналітичної оцінки.

Мета статті: на основі ретроспективного аналізу встановити основні підходи П. Житецького до розкриття історії розвитку соціальних інститутів на українських землях в давні часи.

Праці П. Житецького не втратили своєї наукової вартості, адже присвячені вони насамперед історії української мови, та водночас проливають світло і на історію українського народу, розвиток його культури, взаємозв' язки з іншими слов' янськими народами [9, с. 126].

У науковій спадщині П. Житецького постає величезний комплекс питань, що й у наш час потребують подальшої розробки. Полишаючи застарілі положення і твердження першого історика української літературної мови як факту минувшини, ми звертаємося до тих із його думок і висновків, які й зараз можуть дати нам певні свідчення про походження та розвиток українського народу.

Для здійснення ретроспективного аналізу історії становлення соціальних інститутів виховання на українських землях в давні часи проаналізуємо основні події та ставлення до них, які подані у різних працях ученого.

До вивчення історичного процесу П. Житецький підходив 3 позицій позитивістського еволюціонізму, вважаючи, що населення України, починаючи 3 давньослов'янських племен, було пов' язане ланцюгом спадкоємності [10, с. 80].

У процесі науково-педагогічної діяльності, пов'язаної $з$ дослідженням історії розвитку українського народу, П. Житецький у своїй праці «Теория поэзии» зробив спробу класифікації розвитку головних груп індоєвропейських племен.

Учений також висуває гіпотезу, що «...на найвищих еволюційних щаблинах розвитку ку- 
льтури, в уявленнях найдревніших людей існували лише передчуття релігійних вірувань у вигляді повір'їв ...та в найгрубіших формах фетишизму» $[7$, с. 25].

Скептично П. Житецький ставився до казок як форми передачі історичного змісту подій. Адже «...у казці забагато вигаданих, фантастичних образів ... тому, переходячи від покоління до покоління, казка втрачала своє історичне значення» $[7$, с. 35].

I зовсім іншого сенсу учений надавав народним обрядовим пісням, народним билинам та історичним пісням, адже в них уже знайшли своє відображення релігійні вірування та історичні події у слов'яно-руських племен $[7$, c. 36-94].

П. Житецький зазначав: «Боротьба за віру батьків, за «благочесті», як говорили в старовину, заповняє багато сторінок в історії українського народу. I необхідно зазначити ще, що боротьбу цю вела не сама простонародна маса; не відставали від загальної справи всі верстви українського громадянства» [8, с. 63].

У праці П. Житецького «Община и единодержавие в Киевской Руси», знаходимо згадку про IX століття, де автор детально аналізує землеробський спосіб життя і сімейні цінності полян, які вважав притаманними й для українців. Педагог відзначає, що «...в полян шанувалися сімейні звичаї та землеробська праця» [12, арк. 4 зв.]. Характерними рисами вчений визначає провідну роль сім'ї, працелюбність, осілий спосіб життя [4, с. 33].

П. Житецький відзначав, що на формування культури давніх слов'ян впливало географічне положення - саме тяжка землеробська праця сприяла розвитку родинного ладу: «...продукт землеробського побуту - сім'я, ... сприяє розвитку особистості та становленню поваги у ставленні до старших в роді ... 3 розвитком особистості змінюється суспільний лад роду» [12, арк. 4 зв. -5 зв.].

Негативну оцінку дає П. Житецький наслідкам приєднання українських земель до складу Великого князівства Литовського і Польщі: «Ціле століття... землі постійно переходили 3 рук в руки... а їх населення розтрачувало свої сили в непродуктивній боротьбі під чужими знаменами...». Попри це, він відзначає, що вдавалося зберегти самобутність та надбання українського народу [4, с. 277].

П. Житецький яскраво показав представників київської ученості, i їх роль у боротьбі за самобутність українського народу. 3 цього приводу він зазначав: «Звертаючись до епохи відродження соціально-культурного життя на Україні, тобто до XVI ст. української історії, ми бачимо в становищі старцівської братії дещо нове. Вона теж стоїть під захистом церкви, але ця церква в католицькій державі не користується охороною влади. Навпаки, з часів брестської унії вона являється об'єктом систематичного переслідування 3 боку держави. Сам народ повинен був захищати церкву і в ній шукати підпори для боротьби 3 ворогами. 3'явилися братства, котрі внесли в організацію церковного життя свідомість народних потреб та інтересів. Між цими інтересами значне місце дістала філантропія - головним чином, шляхом влаштування «шпиталів» для старцівської братії. Це були не лікарні, але богадільні, де жили знівечені старці, переважно сліпі. Користуючись допомогою парафіян, ті церкви, при яких були шпиталі, промишляли і на стороні через жебрання милостині. Кожний шпиталь входив до складу «старечого» братства або цеху, що складався 3 декількох шпиталів одного міста або села. Цех мав своє майно, свої права i обов' язки - головним чином, відносно до церкви. Майже не було церкви без шпиталю...» [8, с. 109].

Великого значення учений надає соціальному розвитку суспільства. Так, наприклад, він зазначає: «У першій половині XVIII ст. в трьох полках Лівобережної України було 589 шпиталів. У нас нема статистичних відомостей про число шпиталів в давніші часи, але звістки про шпиталі стріваються досить часто, починаючи з XVI ст., і особливо цікаво те, що з самого початку XVII ст. з'являються військові шпиталі - в 1601 р. в Трехтемирові, а в 1629 р. в Києві „для людей рицарських, покалічених в боях"» $[8$, с. 109].

3 праці «Странствующие школьники в старинной Малороссии» дещо дізнаємося про освіту на території України в період XVIIXVIII ст., зокрема про народні школи та соціальне виховання в них. П. Житецький їх розглядає 3 погляду розумового та морального життя народу: «3 уривочних статистичних відомостей, що дійшли від XVIII ст., можна бачити, як сильно були поширені народні школи в давній Україні. Звичайно, разом 3 церквою будували й школу: тут жив пан дяк зі своєю громадою співаків та читальників церковних. Вже з цього зрозуміло, що справа йде про явище не випадкове, утворене під впливом чужих міркувань, а базується на народному світоглядові та народних симпатіях...» [8, с. 29].

Майже при кожній церкві було два або три священики і лише один дяк, вибраний громадою за добрий норов, за знання та дотримання церковних канонів. Також у дяка мав бути педагогічний талант. Як учителя народної школи - його називали «пан-бакаляр» [5, с. 190]. 3 наведених свідчень бачимо, що до освіти українська громада ставилася дуже серйозно та вимогливо, зокрема й до особи вчителя.

Навчав «пан-бакаляр» молодших школя- 
рів, які жили в школі або приходили до неї. Жили в школі безпритульні сироти, а прихожими були діти козаків та вельможів, іноді бідних [5, с. 190].

Про бажання батьків дати освіту та краще життя дітям красномовно свідчать такі наведені П. Житецьким рядки: «В одній відомій вертепній драмі йдеться про те, що Клим та його дружина люди бідні, але це не завадило відправити сина до школи, причому за навчання вони платили замість грошей свинями...» [5, с. 190].

П. Житецький зазначав, що життя в народних школах, особливо для молодших школярів, було «голодне», але їх зігрівала надія, що скоро вони стануть дяками, а потім і священиками [5, с. 191]. Матеріал для вивчення був надзвичайно об'ємним, і не всім вдавалося перейти на наступний щабель навчання. Особливо важко давалося навчання граматики. Використовували тут і тілесні покарання [5, с. 191].

Були в таких школах і так звані суботники, під час яких учні розповідали учителю все, що вивчили за тиждень, неуспішні отримували «суботника» (покарання). Отож, школа була суворою [5, с. 192].

У народі ж такі школи називали народними училищами, і в кінці XVIII ст. Катерина II почала їх поширювати по Малоросії.. Вони стали розплідником майбутніх чиновників, канцеляристів і т.п. Але така школа не задовольняла суспільство, адже була занадто пристосована до естетичних та літературних уподобань церковних чинів [5, с. 192].

Переглянувши чимало шкільних збірників, складених у XVIII ст. і на початку XIX ст. і призначених для практичного вжитку в школі і поза школою, П. Житецький зробив висновок, що своїм форматом вони нагадують наші записні книжки і містять в собі силу-силенну всяких віршів на мовах слов'янській, книжній українській, народній українській і навіть польській. Часто трапляються в цих збірниках і народні пісні 3 нотами і без них [8, с. 31]. Авторами цієї літератури швидше за все були спудеї - вихідці 3 вищих латинських шкіл та мандрівні дяки [5, с. 193$]$.

3 цього приводу учений зазначав: «Загальні риси моральних мотивів широко розкриті в старих шкільних збірниках і цілком схожі до народного світогляду. Для нас важніше в цьому разі документально пересвідчитись в тому, що стародавня українська школа брала живу і безпосередню участь у виробленні цього світогляду» $[8$, с. 53].

П. Житецький зробив висновок, що у період XVIII ст. і на початку XIX ст. була жива спільність між школою та народом. Багато пере- хресних стежок топталося від народу до школи і навпаки, багато людей ходило цими стежками, несучи в школу народній світогляд і виносячи 3 неї наукові методи думки та мови [8, с. 29].

Вартий уваги, в контексті розвитку соціального виховання, опис образу вчителя: «Ми бачили, що учителі - далеко не вільні були від усяких моральних вад, почасти неминучих в тім становищі, яке вони займали: без стерна і правила йшли вони назустріч всім випадкам життя, не відчуваючи на собі тяжкість науки, повсякчас користуючись «бездільними шпаргалами». Маючи на увазі таке становище наших стародавніх учителів, ми не відважуємося в рішучому тоні ганьбити їх із погляду сьогочасних нам етичних вимог до народного вчителя. Знаємо ми, що і в той час могли дивитись на них 3 докором люди, котрі вчились в тих таки латинських школах, але, дякуючи своїм здібностям та щастю, проклали собі більш широкий шлях життя. Погляди цих людей, теж не святих з усякого іншого погляду, менше всього можуть бути надійною підставою для оцінки дрібних діячів просвіти, котрі задовольнялися мізерною та простою долею сільських бакалярів, і тому не лишили після себе славетних імен, зазначених в історії країни. А проте, саме в них, на нашу думку, і містилася вся сила просвітнього руху, котрий був розпочатий народом і не відривався в старовину від народного грунту. Ця взаємочинність народних і книжних впливів, у зв'язку з рухливим складом стародавньої української школи, багато чого з'ясовує нам як в історії, так і у світогляді українського народу...» [8, с. 29].

Важливою для розуміння соціального розвитку українського народу є праця П. Житецького «Малорусские вирши исторического содержания» (1892) [3, с. 313-332].

Головною ідеєю в історичних думах, на переконання автора, є «ідея волі від насилля всякого роду над особою людини». Вона виражена не абстрактно, а у вигляді «певних та ясних змагань до класової рівноправності». Класовий підхід П. Житецького до характеристики історичних дум чітко виражений в аналізі думи про Ганджу Андибера, яка «...змальовує класовий розбрат серед самого козацтва, але всі симпатії іiі на боці більшості, зневаженої «дуками-срібляниками» [3, с. 315]. Тут маємо ще один потужний вияв прогресивного світогляду П. Житецького, його широкий погляд на категорію соціальності як визначальну в історично-філологічних дослідженнях.

Привертають до себе увагу наведені П. Житецьким трактування віршованого жанру в конкретно історичний - відомої історичної події під назвою «уманська різня» 1768 р. Автор вказав, 
що пісня не мала вигаданих фактів, адже створювалась під впливом щойно отриманих вражень. Соціально-історичні процеси найбільш влучно відображають такі записані П. Житецьким рядки:

«В Умань же ми пішли,

Тай почали штурмувати,

Там багато панів найшло,

Тай давай їм ніжки розправляти...» [3, с. 329].

Під сумнів П. Житецький ставив кількість війська М. Залізняка, адже в одних піснях називається сорок тисяч, а в інших - одна. Близький дослідник до думки, що пісня ця складена одним з учасників наступу на місто. Наводить учений i рядки, які засвідчили жорстокість тих подій:

«...Ой пішов Швачка головкою шити,

Ляхів, жидів по Умані лупити,

А наш Неживий цокоче,

Аж Умань зубами скрегоче.

А Журба, ходячи, зажурився,

Що головко бідний, Умань загорівся...»

$[3$, c. 329].

П. Житецький робить висновок, що така душевна пісня 3 народним настроєм, хвилюваннями та життєвими проблемами майже не містить цензури, а отже, надає достовірні факти перебігу подій [3, с. 331].

Впадає в око притаманна тому періодові термінологія П. Житецького у роботі «Творцы и певцы малорусских дум» (1892), відносно осіб 3 інвалідністю [6, с. 213]. Каліки, старці - поняття, пов'язані 3 людською неміччю, фізичними вадами, беззахисністю. Поєднати ці поняття $з$ величною героїкою дум, їхніми високоморальними ідеями дуже важко. Звичайно, П. Житецький мав на увазі ветеранів, які доживали віку та заліковували бойові рани в різних громадських притулках, якими, зокрема, й були церковні шпиталі та школи в XVII-XVIII ст. на території українських земель [11, с. 141].

Дбаючи про збереження та розвиток національних цінностей, П. Житецький приділяв особливу увагу вивченню суспільних перетворень, починаючи з первісного ладу до XVIII ст., щоб довести процес самостійного відокремленого формування української мови та літератури. Погляди та оцінки вченого минулого українського народу стали рушійною силою у його подальшій просвітницькій боротьбі за самобутність українського народу.

На основі аналізу праць педагога нам вдалося розглянути найважливіші етапи в розвитку соціального виховання, освіти, культури, релігії та наукової думки українського народу, вплив на його світогляд братніх народів, та процес їх відокремлення. На думку вченого, об'єктивною формою передачі соціальних знань були народні обрядові пісні, народні билини та історичні пісні (на відміну від казок, які «завуальовували дійсність»). У праці П. Житецького «Община и единодержавие в Киевской Руси» (1865) названо особливості соціального виховання, притаманні українцям (провідна роль сім'ï, працелюбність і осілий спосіб життя). Перспективним напрямом подальших наукових може бути порівняльний аналіз підходів П. Житецького до розкриття історії становлення соціального виховання на давніх українських землях та інших вітчизняних просвітників певної історичної доби.

\section{СПИСОК ВИКОРИСТАНИХ ДЖЕРЕЛ}

1. Бегас Л. Д. Історичні аспекти розвитку соціальної педагогіки як науки, ії предмет, мета, завдання та особистість соціального педагога. Збірник наукових праць Кам'янець-Подільського національного університету імені Івана Огієнка. Серія: Соціально-педагогічна. 2019. Вип. 32. С. 517. URL: http://nbuv.gov.ua/UJRN/znpkp_sp_ 2019_32_3

2. Варецька О. В. Питання розвитку соціальної компетентності вчителя в наукових працях (від давніх часів до середини XIX століття). Педагогіка формування творчої особистості у вищій $і$ загальноосвітній школах. 2014. Вип. 35. C. 10-21. URL: http://nbuv.gov.ua/UJRN/Pfto_ 2014_35_3

3. Житецкий П. И. Очерк звуковой истории малорусского. К.: Университетская типография, 1876. 380 с.

4. Житецкий П. Малорусские вирши исторического содержания. Киевская старина. 1892. № 9. С. 313-332.

5. Житецкий П. Странствующие школьники в старинной Малороссии. Киевская старина. 1892. № 21. С. 189-205.

6. Житецкий П. Творцы и певцы малорусских дум. Киевская старина. 1892. № 11. С. 213-231.

7. Житецкий П. Теория поэзии. К.: Тип. Окружн. штаба, 1898. 302 с.

8. Житецький П. Про українські народні думи. К.: Печатня Видавничого Тов-ва «Друкар», 1919. 116 c.

9. Жовтобрюх М. А. Видатний український вчений П. Г. Житецький. Украӥнський історичний журнал. 1967. № 1. С. 126-128.

10. Казакевич О. Павло Житецький. Життя та діяльність. К.: Фітосоціоцентр, 2008. 204 с.

11. Плачинда В. П. Павло Гнатович Житецький. К.: Наукова думка. 1987. 207 с.

12. Житецкий П. «Община и единодержавие в Киевской Руси». Рассуждение, написанное для получения степени кандидата историкофилологического факультета Павлом Житецким. Державний архів міста Києва. Ф. 16. Київський університет Св. Володимира. Оп. 471. 
Спр. 186. 47 арк.

13. Житецкий П. И. История Древней Руси. Автограф. Кон. XIX в. Інститут рукопису Національної бібліотеки України імені В.І. Вернадського. Ф. I. Комплексний фонд «Літературні матеріали». Зібрання літературних творів і зібрання документів поч. XII-XX ст. Спр. 46607.80 арк.

\section{REFERENCES}

1. Behas, L. D. (2019). Istorychni aspekty rozvytku sotsial'noi pedahohiky yak nauky, yii predmet, meta, zavdannia ta osobystist' sotsial'noho pedahoha. Zbirnyk naukovykh prats' Kam'ianets'Podil's'koho natsional'noho universytetu imeni Ivana Ohiienka. Seriia: Sotsial'no-pedahohichna, Issue 32, 5-17. URL: http://nbuv.gov.ua/UJRN/znpkp_ sp_2019_32_3 [in Ukrainian].

2. Varets'ka, O. V. (2014). Pytannia rozvytku sotsial'noi kompetentnosti vchytelia $\mathrm{v}$ naukovykh pratsiakh (vid davnikh chasiv do seredyny XIX stolittia). Pedahohika formuvannia tvorchoi osobystosti $u$ vyshchii $i$ zahal'noosvitnii shkolakh, Issue 35, 10-21. URL: http://nbuv.gov.ua/UJRN/Pfto_ 2014_35_3 [in Ukrainian].

3. Zhitetskiy, P. I. (1876). Ocherk zvukovoy istorii malorusskogo narechiya. Universitetskaya tipografiya. K.: Universitetska [in Russian].

4. Zhitetskiy, P. (1892). Malorusskiye virshi istoricheskogo soderzhaniya. Kiyevskaya starina, Issue 9, 313-332 [in Russian].
5. Zhitetskiy, P. (1892). Stranstvuyushchiye shkolniki $\mathrm{v}$ starinnoy Malorossii. Kiyevskaya starina, Issue 21, 189-205 [in Russian].

6. Zhitetskiy, P. (1892). Tvortsy i pevtsy malorusskikh dum. Kiyevskaya starina, Issue 11, 213-231 [in Russian].

7. Zhitetskiy, P. (1898). Teoriya poezii. K.: Tip. Okruzhn. shtaba [in Russian].

8. Zhytetskyi, P. (1919). Pro ukrainski narodni dumy. K.: Pechatnia Vydavnychoho Tov-va «Drukar» [in Ukrainian].

9. Zhovtobriukh, M. A. (1967). Vydatnyi ukrainskyi vchenyi P. H. Zhytetskyi. Ukrainskyi istorychnyi zhurnal, Issue 1, 126-128 [in Ukrainian].

10. Kazakevych, O. (2008). Pavlo Zhytetskyi. Zhyttia ta diialnist. K.: Fitosotsiotsentr [in Ukrainian].

11. Plachynda, V.P. (1987). Pavlo Hnatovych Zhytetskyi. K.: Naukova dumka [in Ukrainian].

12. Zhiteckij, P. «Obshhina i edinoderzhavie v Kievskoj Rusi». Rassuzhdenie, napisannoe dlja poluchenija stepeni kandidata istorikofilologicheskogo fakul'teta Pavlom Zhiteckim. Derzhavnyi arkhiv mista Kyieva. F. 16. Kyivskyi universytet Sv. Volodymyra. Op. 471. Spr. 186. 47 ark. [in Russian].

13. Zhiteckij, P. I. Istorija Drevnej Rusi. Avtograf. Kon. XIX v. Instytut rukopysu Natsionalnoi biblioteky Ukrainy imeni V. I. Vernadskoho. F. I. Kompleksnyi fond «Literaturni materialy». Zibrannia literaturnykh tvoriv i zibrannia dokumentiv poch. XII-XX st. Spr. 46607.80 ark. [in Russian]. 